\title{
New Perspectives on Investing in Emerging Markets
}

\author{
Michael J. Schill \\ Darden Graduate School of Business Administration \\ University of Virginia
}

This review of recent academic research in emerging market finance illustrates the unique features of emerging market investing and the effect of these features on traditional principles of investing. The effects of information inequities, illiquidity, poor investor protection, and increased integration on investment decisions in emerging markets are highlighted.

What makes investing in emerging markets unique? Shouldn't one expect the principles that hold for investing in the United States to also hold for Uruguay? Shouldn't diversification always reduce portfolio risk? Shouldn't the arbitrage mechanism always reduce mispricing? Shouldn't riskier securities always demand higher expected returns?

Current academic research indicates that, although the fundamental behavior of participants in capital markets is the same, emerging markets contain unique governmental and other institutional features that create distinct differences in the way investors must approach their investment strategies. This review of recent academic research in emerging market finance attempts to capture the state of thinking on those features that call into question the applicability of traditional principles of investing to such markets.

\section{The Market Synchronicity Puzzle}

Traditional portfolio theory suggests that the risk of a security can be divided into two components: market risk and company risk. Market risk measures the tendency for stocks to move together, whereas company risk measures the unique variation. One measure of the importance of market risk is the percentage of stocks in the market that move together over a particular period. A market in which all stocks move in the same direction is said to maintain high "market synchronicity" (sometime called "market synchrony"). A market where only half of the stocks move in the same direction would be said to maintain low market synchronicity. If we look at stock returns in the United States over a typical week, we observe that about 58 percent of the stocks move in the same direction for the week. For stock returns in emerging markets, this measure of co-movement is much higher. For example, in Malaysia, the percentage of stocks that move in the same direction over an average week is 75 percent. In China and Poland, 80 percent and 83 percent, respectively, of stocks co-move in the average week. Table 1 provides estimates of co-movement for a sample of countries.

The finding that stock returns in developed market economies tend to move in a relatively nonsynchronous pattern and that stock returns in emerging markets tend to move in a relatively synchronous pattern was first documented and analyzed by Morck, Yeung, and Yu in the late 1990s. ${ }^{1}$ Morck, Yeung, and Yu (2000) provided convincing evidence that the return correlations patterns are not generated by correlation in economic fundamentals. If fundamentals do not drive stock returns, classic finance theory has a difficult time explaining the puzzling variation in synchronicity across markets. The market synchronicity puzzle serves as an illustration in this review of the particular market features that make emerging market finance unique.

1Morck, Yeung, and Yu (2000) provides the original research; Morck and Yeung (2002) is a more readable treatment of the same material. 
Table 1. Emerging Market Characteristics

\begin{tabular}{|c|c|c|c|c|c|c|c|c|}
\hline & $\begin{array}{c}\text { \% Stocks } \\
\text { Moving in Step }\end{array}$ & $\begin{array}{l}\text { Insider Trading Law: } \\
\text { Exist/Enforce }\end{array}$ & Zero Returns & LOT & Turnover & $\begin{array}{l}\text { Short } \\
\text { Selling? }\end{array}$ & $\begin{array}{c}\text { Block } \\
\text { Premium }\end{array}$ & $\begin{array}{c}\text { Anti-Self- } \\
\text { Dealing Index }\end{array}$ \\
\hline United States & $58 \%$ & $1934 / 1961$ & & & & Yes & $1 \%$ & 0.65 \\
\hline \multicolumn{9}{|l|}{ Latin America } \\
\hline Argentina & NA & $1991 / 1995$ & $25 \%$ & $4 \%$ & $4 \%$ & No & $27 \%$ & 0.44 \\
\hline Brazil & $65 \%$ & 1976/1978 & 39 & 7 & 5 & No & 65 & 0.29 \\
\hline Chile & 67 & $1981 / 1996$ & 43 & 5 & 1 & No & 18 & 0.63 \\
\hline Colombia & 72 & 1990/None & 54 & 7 & 1 & No & 27 & 0.58 \\
\hline Mexico & 71 & 1975/None & 23 & 4 & 4 & Yes & 34 & 0.18 \\
\hline Peru & 71 & 1991/1994 & 44 & 7 & NA & No & 14 & 0.41 \\
\hline Venezuela & NA & 1998/None & 25 & 5 & 2 & No & 27 & 0.09 \\
\hline \multicolumn{9}{|l|}{ East Asia } \\
\hline China & $80 \%$ & 1993/None & $5 \%$ & $2 \%$ & NA & No & NA & 0.78 \\
\hline Korea & 70 & 1976/1988 & 12 & 3 & $14 \%$ & No & $16 \%$ & 0.46 \\
\hline Philippines & 69 & 1982/None & 43 & 9 & 2 & No & 13 & 0.24 \\
\hline Taiwan & 76 & 1988/1989 & 10 & 2 & 21 & No & 0 & 0.56 \\
\hline \multicolumn{9}{|l|}{ South Asia } \\
\hline India & $70 \%$ & $1992 / 1998$ & $24 \%$ & $5 \%$ & $9 \%$ & NA & NA & 0.55 \\
\hline Indonesia & 67 & 1991/1996 & 48 & 10 & 5 & No & $7 \%$ & 0.68 \\
\hline Malaysia & 75 & 1973/1996 & 21 & 3 & 3 & Yes & 7 & 0.95 \\
\hline Pakistan & 66 & 1995/None & 36 & 7 & 28 & No & NA & 0.41 \\
\hline Singapore & 70 & 1973/1978 & 34 & 4 & NA & Yes & 3 & 1.00 \\
\hline Sri Lanka & NA & 1987/1996 & 56 & 10 & NA & NA & NA & 0.41 \\
\hline Thailand & 67 & $1984 / 1993$ & 29 & 5 & 7 & Yes & 12 & 0.85 \\
\hline \multicolumn{9}{|l|}{ Europe } \\
\hline Czech Rep. & $69 \%$ & $1992 / 1993$ & $29 \%$ & $5 \%$ & NA & Yes & $58 \%$ & 0.34 \\
\hline Greece & 70 & 1988/1996 & 15 & 3 & $3 \%$ & No & NA & 0.23 \\
\hline Hungary & NA & $1994 / 1995$ & 20 & 4 & NA & No & NA & 0.20 \\
\hline Poland & 83 & $1991 / 1993$ & 17 & 4 & NA & No & 13 & 0.30 \\
\hline Portugal & 61 & 1986/None & 39 & 5 & 3 & Yes & 20 & 0.49 \\
\hline Russia & NA & 1996/None & 43 & 12 & NA & NA & NA & 0.48 \\
\hline Turkey & 74 & $1981 / 1996$ & 18 & 5 & 11 & No & 37 & 0.43 \\
\hline \multicolumn{9}{|c|}{ Middle East/Africa } \\
\hline Egypt & NA & 1992/None & $14 \%$ & $3 \%$ & NA & NA & $4 \%$ & 0.49 \\
\hline Israel & NA & 1981/1989 & 29 & 5 & NA & No & 27 & 0.71 \\
\hline Morocco & NA & 1993/None & 43 & 4 & NA & NA & NA & 0.57 \\
\hline South Africa & $67 \%$ & 1989/None & 40 & 7 & NA & Yes & 2 & 0.81 \\
\hline Zimbabwe & NA & None/None & 52 & 12 & 1 & No & NA & 0.44 \\
\hline
\end{tabular}

Notes: The data used in this table come from several specific research articles. "\% Stocks Moving in Step" is the percentage of stocks moving in the same direction over an average week in 1995 (Morck, Yeung, and Yu 2000, Table 2). "Insider Trading Law" is the year that insider trading law was enacted at the exchange ("Exist") and the year of the first prosecution as of 1997 ("Enforce") (Bhattacharya and Daouk 2002, Table 1). "Zero Returns" is the median number of zero returns over one quarter for equities in the market scaled by the total number of available trading days (Lesmond 2005, Table 1). "LOT" is the median Lesmond-Ogden-Trzcinka estimate of how far the local market index must move to motivate company-specific stock trading; it is used here as a measure of illiquidity (round-trip transaction costs) for equities in the market (Lesmond 2005, Table 1). "Turnover" is the mean ratio of monthly value traded divided by the company market capitalization (Bekaert, Harvey, Lundblad 2005, Table 1). "Short Selling?" identifies whether short selling is practiced as documented by Bris, Goetzman, and Zhu (2004). "Block Premium" is the average difference between prices paid for a control block of shares and the price on the exchange two days after control transaction announcements (Dyck and Zingales 2004, Table 2). "Anti-Self-Dealing Index" is a measure of legal protection of minority shareholders against expropriation by corporate insiders (Djankov, La Porta, Lopez-de-Silanes, and Shleifer 2005, Table 3).

$\mathrm{NA}=$ not available. 


\section{Feature 1: Information Inequities}

One unique feature of emerging markets is the presence of significant information inequities among investors. The traditional efficient markets view is that news is distributed widely and instantaneously so prices can and do reflect all public information. But many of the institutional mechanisms for information dissemination in developed markets are commonly missing in emerging markets. In some instances, public company-level information may be almost completely missing. In such circumstances, market synchronicity can occur because outside investors receive only marketwide news and thus only marketwide news changes prices (Durnev, Morck, Yeung, and Zarowin 2003; Jin and Myers 2006). The tendency for emerging markets to exhibit patterns of synchronicity emphasizes a tendency toward substantially greater asymmetry in company information, so insiders know considerably more about the company than do outside investors. This information asymmetry creates an uneven playing field that fundamentally affects investing decisions. Current research explores various aspects of this difference: insider trading regulation, information advantage, and financial disclosure.

Insider Trading Regulation. In developed markets, company news (e.g., earnings announcements) is generally associated with important and immediate price changes. The information environment in emerging markets may deviate from the standard assumption of the semistrong form of efficiency. A study by Bhattacharya, Daouk, Jorgenson, and Kehr (2000) on Mexican stock returns confirmed that for some classes of stock, companyspecific announcements are generally associated with no change in stock prices. More specifically, prices for shares restricted to Mexican investors tend to not react to Mexican corporate news announcements, but shares restricted to foreigners do react to the same news. The difference in return behavior can be explained by earlier rampant insider trading (trading by those who have nonpublic information) of the domestic shares. Although it is illegal to trade on nonpublic information in Mexico, prosecution is rare. Research by Bhattacharya and Daouk (2002) confirmed that insider trading is common among emerging markets and, more importantly, that it is priced; investors require higher return premiums where insider trading is not prosecuted. ${ }^{2}$

Table 1 summarizes the state of insider trading laws and prosecution in emerging markets. As might be expected, the presence of insider trading has a profound effect on the incentives for equity research and other forms of information dissemination. Empirically, research by Bushman, Piotroski, and Smith (2005) found that insider trading in emerging markets tends to drive out analyst coverage. Yet, once insider trading begins to be prosecuted, analyst coverage in the market tends to increase. The findings support the notion that unprosecuted insider trading makes the information inequities even worse.

Domestic vs. Foreign Information Advantage. A related debate concerns the equality of information in emerging markets between foreign investors and local investors. Past research has shown that geography affects investor performance. For example, as shown by Coval and Moskowitz (2001), in the United States, investors located closer to company headquarters tend to achieve better returns than investors located farther away from the company. Current thinking maintains that geographic location is particularly important in emerging markets but direction of the inequity is unclear. One line of research (see Brennan and Cao 1997) argues that local investors in emerging markets naturally have an information advantage over foreigners. A new line of research suggests that foreign investors actually tend to perform better than locals in their selection and timing in emerging market investing. For example, Froot, O'Connell, and Seasholes (2001) and Seasholes (2004) provided evidence of a foreign investor advantage in broad market timing and stock selection for Taiwanese investments. Yet, Barber, Lee, Liu, and Odean (2005) found that the advantage of foreigners disappeared once they controlled for systematic performance differences between retail investors and institutional investors.

2Bris (2005) provided contradicting evidence on the benefits of insider trading restrictions. 
Financial Disclosure. One reason for information inequities among investors in emerging markets is arguably a lack of transparency of earnings disclosure resulting from at least one of three things: poor accounting standards, perverse managerial motivations, and/or lack of enforcement (e.g., credible auditing). A study by Bhattacharya, Daouk, and Welker (2003) examined earnings aggressiveness, loss avoidance, and earnings smoothing in emerging markets and found that earnings transparency is priced: Companies that provide better earnings transparency are associated with lower required return premiums in emerging market stocks (and lower required return premiums are associated with higher valuation). Bae, Stulz, and Tan (2005) examined analyst earnings forecasts and found that when company information is less transparent, local analysts provide more informative estimates than foreign analysts.

\section{Feature 2: Market Illiquidity}

Another explanation for the synchronicity effect in emerging markets is the presence of abnormal illiquidity and other forms of transaction costs. Empirical data confirm that emerging market securities are commonly more illiquid. Lesmond (2005) conducted a comprehensive overview of equity market liquidity among these markets. He found that market liquidity varies considerably across emerging markets. Some markets, such as Taiwan, exhibit liquidity levels typical of developed markets, but most emerging markets exhibit substantially lower liquidity levels. Table 1 provides three country liquidity estimates: the frequency of zero returns, the LOT (for Lesmond-Ogden-Trzcinka) transaction cost estimate, and the rate of security turnover. Some evidence indicates that transaction costs vary by whether the investor is domestic or foreign. In a prominent study by Choe, Kho, and Stulz (2005), foreign money managers in South Korea were found to systematically pay a 21 basis point higher cost to purchase equity and a 16 basis point higher cost for equity sales. Such transaction cost inequities are not commonly found for investors in developed markets.

Short-sale restrictions, common in emerging markets, also decrease the ease of trading. Although short-sale restrictions are frequently implemented as measures to protect investors from market manipulation, one study by Bris, Goetzmann, and Zhu (2004) found that such restrictions tend to do the opposite and make prices less efficient. The conclusion is that regulatory agencies in emerging markets drive out the disciplining effects of arbitrage capital by restricting short sales. A summary of where short selling is practiced in emerging markets is provided in Table 1.

An important question in finance is whether liquidity affects return premiums. Bekaert, Harvey, and Lundblad (2005) tested for a liquidity premium in emerging market returns and found that investors require higher returns in markets that experience greater marketwide illiquidity. Their study confirmed that the emerging market illiquidity premium tends to decline once the market is opened up to outside investors.

\section{Feature 3: Poor Investor Protection}

Another feature common to emerging markets is a relative lack of protection from investor expropriation. Shleifer and Vishny in a 1997 study proposed that the central company governance problem is the toleration of investor expropriation. This finding holds particularly true in emerging markets; Desai and Moel (2005) provided an interesting example of such expropriation and its aftermath in a Czech company. Another explanation for market synchronicity effects explored by Morck, Yeung, and Yu (2000) is that weak investor protection laws do not promote informed investing so company-specific information never gets priced by the market.

Table 1 includes two indices of investor expropriation. The first index, block premium, promoted by Dyck and Zingales (2004), is based on the average premium that investors are willing to pay to gain control of a company. If corporate control is associated with greater private benefits, such as expropriation, this measure provides a market-based measure of expropriation. The second index, the anti-self-dealing index, by Djankov, La Porta, Lopez-de-Silanes, and Shleifer (2005), is meant to improve on the well-known La Porta, Lopez-de-Silanes, Shleifer, and Vishny (1997) anti-director-rights index by measuring the effective legal enforcement mechanisms available to minority shareholders. 
The lack of investor protection is associated with a number of effects: lower company valuation (La Porta, Lopez-de-Silanes, Shleifer, and Vishny 2002), lower foreign investor participation (Leuz, Lins, and Warnock 2005), and lower analyst coverage (Lang, Lins, and Miller 2004). A variety of solutions have been proposed for poor investor protection environments. One solution is to improve the system in the home market. Dyck and Zingales (2004) indicated that tax policy changes or the encouragement of media pressure are the most successful influences for increasing investor protections in emerging markets. An alternative solution is for emerging market companies to opt into a better foreign governance structure by bonding themselves to the foreign legal system. Evidence suggests that corporate valuations rise for companies that adopt a foreign governance structure by borrowing foreign debt (Harvey, Lins, and Roper 2004), listing on a foreign equity market (Doidge, Karolyi, and Stulz 2004), or employing a "Big Five" auditor (Fan and Wong 2002). 3 The critics of the effects of foreign law argue that investors should be leery of the power of a foreign legal system to deter abuse for an extended period of time (see Siegel 2005; Bris, Cantale, and Nishiotis 2005).

\section{Feature 4: Increased Integration}

A final feature of emerging capital markets is a recent, important decline in their distinctiveness. Across the globe, capital markets are becoming more integrated, and this increasing integration is particularly important for emerging markets. ${ }^{4}$ Market liberalization and integration have had a marked effect on market synchronicity, and most emerging markets have experienced a decline in synchronicity measures since the early 1990 s. $^{5}$ A number of studies have examined how liberalization has affected valuation and the ownership structure of emerging market companies. One study by Bekaert, Harvey, and Lumsdaine (2002) motivates and documents the differences between the official liberalization dates (defined by government policy) and the effective liberalization date (defined by investor behavior) of emerging capital markets. The finding is that the integration of an emerging market does result in an increase in company valuations (Bekaert and Harvey 2003) and a broadening of ownership (Ammer, Holland, Smith, and Warnock 2005; Warnock and Cai 2004; Ferreira and Matos 2006).

\section{Summary}

Capital markets in emerging economies share a number of unique institutional features that alter the traditional investment paradigms. This article introduced four features that have attracted attention in the academic community: information inequities, security illiquidity, poor investor protection, and increased integration. These features serve as warning flags indicating that investors in emerging markets face abnormal costs in information disadvantage, illiquidity, and investor expropriation risk. Yet, despite the current additional challenges for investment, there is agreement that many of the features that make emerging market investing so unique are diminishing as the global capital market expands.

This publication qualifies for 1 CE credit.

\footnotetext{
${ }^{3}$ Gozzi, Levine, and Schmukler (2005) and Sarkissian and Schill (2006) observed that much of the valuation gains achieved by opting into a foreign legal system are temporary.

4Edison and Warnock (2003) provided some evidence on market integration among emerging markets.

5 Li, Morck, Yang, and Yeung (2004) provided evidence of the decline in market synchronicity from the early 1990s to the early 2000s, with a temporary setback during the period of the Asian crisis in the late 1990s.
} 


\section{References}

Ammer, John, Sara B. Holland, David C. Smith, and Francis E. Warnock. 2005. "Look at Me Now: What Attracts U.S. Shareholders." Working paper, University of Virginia.

Non-U.S. companies that cross-list on U.S. exchanges realize an increase in share holdings by U.S. investors.

Barber, Brad M., Yi-Tsung Lee, Yu-Jane Liu, and Terrance Odean. 2005. "Who Gains from Trade, Evidence from Taiwan.” SSRN working paper.

Economically significant market inefficiencies exist in world financial markets as demonstrated by comparing institutional and individual investors in Taiwan. Individual investors suffer an annual performance penalty of 3.8 percentage points. Institutional investors enjoy a performance boost of 1.5 percentage points.

Bae, Kee-Hong, Rene M. Stulz, and Hongping Tan. 2005. "Do Local Analysts Know More? A Cross-Country Study of the Performance of Local Analysts and Foreign Analysts." National Bureau of Economic Research Working Paper 11697.

The authors examine the relationship between the precision of earnings forecasts of local analysts and of foreign analysts for 32 countries and find that local analysts provide more informative estimates than foreign analysts.

Bekaert, Geert, and Campbell R. Harvey. 2003. "Emerging Markets Finance." Journal of Empirical Finance, vol. 10, nos. 1-2 (February):3-56.

This article is a comprehensive overview of emerging market finance.

Bekaert, Geert, Campbell R. Harvey, and Robin L. Lumsdaine. 2002. "Dating the Integration of World Equity Markets.” Journal of Financial Economics, vol. 65, no. 2 (August):203-247.

This study documents the difference between official equity market liberalization dates and "effective" market liberalization dates for a wide cross-section of emerging economies.

Bekaert, Geert, Campbell R. Harvey, and Christian Lundblad. 2005. "Liquidity and Expected Returns: Lessons from Emerging Markets.” NBER Working Paper 11413.

The authors describe a measure of liquidity for emerging markets (a function of the frequency of zeroreturn days across all companies), assess whether such liquidity is a persistent factor in asset prices, and posit a liquidity- and market-risk-based asset-pricing model.

Bhattacharya, Utpal, and Hazem Daouk. 2002. “The World Price of Insider Trading.” Journal of Finance, vol. 57, no. 1 (February):75-108.

Of 103 countries surveyed, 87 had insider trading laws but only 38 had records of prosecution under those laws in the 1990s. Stock returns in a country are not affected by the introduction of such laws but decrease only after the first prosecution.

Bhattacharya, Utpal, Hazem Daouk, and Michael Welker. 2003. "The World Price of Earnings Opacity." Accounting Review, vol. 78, no. 3 (July):641-678.

Earnings opacity, as measured by earnings aggressiveness, loss avoidance, and earnings smoothing, negatively affects country stock returns and trading. 
Bhattacharya, Uptal, Hazem Daouk, Brian Jorgenson, and Carl-Heinrich Kehr. 2000. "When an Event Is Not an Event: The Curious Case of an Emerging Market.” Journal of Financial Economics, vol. 55, no. 1 (January):69-101.

This article documents that company-specific information is fully incorporated into prices before the public announcement in the Mexican Stock Exchange because of unrestricted insider trading.

Brennan, Michael J., and H. Harry Cao. 1997. "International Portfolio Investment Flows." Journal of Finance, vol. 52, no. 5 (December):1851-80.

The bias to domestic investments has been hypothesized to be caused by higher transaction costs, but strong evidence indicates that it is primarily caused by informational asymmetries.

Bris, Arturo. 2005. “Do Insider Trading Laws Work?” European Financial Management, vol. 11, no. 3:267-312. Insider trading laws in emerging markets do not prevent insiders from profiting and, in fact, may make it worse for public investors.

Bris, Arturo, Salvatore Cantale, and George Nishiotis. 2005. "A Breakdown of the Valuation Effects of International Cross-Listing." Working paper.

Cross-listing improves equity liquidity and brings foreign investors to a company, but the cost of improved investor protections and the small increase in valuation is causing foreign companies to be less likely to cross-list.

Bris, Arturo, William N. Goetzmann, and Ning Zhu. 2004. "Efficiency and the Bear: Short Sales and Markets around the World." Yale ICF Working Paper No. 02-45.

The authors re-examine the conjecture that short selling is bad for emerging markets and find that short selling leads to improvements in pricing efficiency and a reduction in crash risk.

Bushman, Robert M., Joseph D. Piotroski, and Abbie J. Smith. 2005. "Insider Trading Restrictions and Analysts' Incentives to Follow Firms.” Journal of Finance, vol. 60, no. 1 (February):35-66.

The authors examine the relationship between insider trading and analyst coverage across 100 countries. Analysts are more likely to follow a country's stocks when insider trading laws are enforced.

Ceva, Kristin Johnson. 2006. "Finding Opportunity in Emerging Market Debt." CFA Institute Conference Proceedings Quarterly, vol. 23, no. 2 (June):30-41. [added April 2008; abstract by author]

Emerging market debt is a more stable asset class now than it was 10 years ago. Improvements in macroeconomic fundamentals and political stability make this a safer market for diversification and yield and less prone to event risk. As spreads on sovereign debt denominated in U.S. dollars have narrowed, investors have sought higher yields offered by local-currency-denominated debt, thereby displaying an appetite for currency risk. Sovereign issuers are showing a preference for raising funds in their own markets, and the commensurate demand from foreign investors has led to the development of new performance indices for local currency bonds.

Chen, Jianguo, Andrea Bennett, and Ting Zheng. 2006. "Sector Effects in Developed vs. Emerging Markets." Financial Analysts Journal, vol. 62, no. 6 (November/December):40-51. [added April 2008; abstract by authors]

This examination of developed and emerging markets suggests that toward the end of the 20th century, sector effects caught up with country effects in the developed markets of the world, as a result of rising sector effects rather than declining country effects. For emerging markets, however, country effects have remained the dominant influence relative to sector effects, although the importance of country effects has been on a steady decline. These results confirm that international equity managers should emphasize sector-based approaches when investing in the developed countries but should continue country-based allocation strategies in emerging markets. 
Chinn, Menzie D. 2006. "The (Partial) Rehabilitation of Interest Rate Parity in the Floating Rate Era: Longer Horizons, Alternative Expectations, and Emerging Markets." Journal of International Money and Finance, vol. 25, no. 1 (February):7-21. [added April 2008; summarized in the CFA Digest, August 2006, by Joseph D.V. Vu, CFA]

Uncovered interest parity (UIP) states that the expected exchange rates between two currencies should be determined by their risk-free interest rate differentials. This makes perfect sense in theory but has not been successful in explaining ex post changes in exchange rates. The author reviews recent studies of UIP, especially as they relate to non-G-7 currencies. He also argues that the more recent evidence against UIP is less strong than generally believed. Nevertheless, the author does not find support over short horizons for the "unbiasedness hypothesis"- the theory that the forward rate is an unbiased predictor of the future spot rate.

Choe, Hyuk, Bong-Chan Kho, and Rene Stulz. 2005. "Do Domestic Investors Have an Edge? The Trading Experience of Foreign Investors in Korea." Review of Financial Studies, vol. 18, no. 3:795-829.

In Korea, foreign investors pay more than domestic investors when making medium and large trades.

Coval, Joshua D., and Tobias J. Moskowitz. 2001. "The Geography of Investment: Informed Trading and Asset Prices." Journal of Political Economy, vol. 109, no. 4 (August):811-841.

Geographic proximity of a mutual fund manager to companies accounts for a 2.67 percent return, which suggests that local investors have an informational advantage.

de Jong, Frank, and Frans A. de Roon. 2005. "Time-Varying Market Integration and Expected Returns in Emerging Markets." Journal of Financial Economics, vol. 78, no. 3 (December):583-613. [added April 2008; summarized in the CFA Digest, May 2006, by Charles F. Peake, CFA]

Integrating emerging markets into world markets takes place gradually over time. The authors use regression analysis to demonstrate the time-varying nature of integration. Reduced market segmentation is statistically and economically significant in reducing the cost of capital in liberalizing emerging markets.

Desai, Mihir A., and Alberto Moel. 2005. "Czech Mate: Expropriation and Investor Protection in a Converging World.” European Corporate Governance Institute Working Paper 62/2004.

This paper provides a case study on foreign-investment expropriation and lessons learned.

Djankov, Simeon, Rafael La Porta, Florencio Lopez-de-Silanes, and Andrei Shleifer. 2005. "The Law and Economics of Self-Dealing." NBER Working Paper 11883.

The anti-self-dealing index examines the extent to which 72 countries protect minority shareholders against expropriation. The index is correlated with stock market outcomes.

Doidge, Craig, Andrew Karolyi, and Rene M. Stulz. 2004. "Why Are Foreign Firms Listed in the U.S. Worth More?” Journal of Financial Economics, vol. 71, no. 2 (February):205-238.

Listing on the U.S. market reduces the ability of controlling shareholders to expropriate minority shareholder and fundamentally explains the higher valuations that cross-listed companies achieve.

Durnev, Artyom, Randall Morck, Bernard Yeung, and Paul Zarowin. 2003. "Does Greater Firm-Specific Return Variation Mean More or Less Informed Stock Pricing?” Journal of Accounting Research, vol. 41, no. 5 (December):797-836.

This study uses the relationship between stock price movements and future earnings to examine whether higher company-specific return variation signals more information-laden stock prices. 
Dyck, Alexander, and Luigi Zingales. 2004. "Private Benefits of Control: An International Comparison.” Journal of Finance, vol. 59, no. 2 (April):537-600.

The authors use controlling block sale premiums to estimate the private benefit of control to block shareholders (expropriation potential) across 39 markets. Although the benefit of control is on average 14 percent firm equity, that benefit is particularly large in emerging markets, with an average of up to 67 percent of firm equity in some countries.

Edison, Hali J., and Francis E. Warnock. 2003. "Cross-Border Listings, Capital Controls, and Equity Flows to Emerging Markets.” International Finance Discussion Paper 770.

Cross-listing an emerging market company on a U.S. exchange brings capital flows into the countrybut only for a short time. Slow U.S. economic activity is correlated with increased capital flows to emerging markets.

Estrada, Javier, Mark Kritzman, and Sébastien Page. 2006. "Countries versus Industries in Emerging Markets: A Normative Portfolio Approach.” Journal of Investing, vol. 15, no. 4 (Winter):19-28. [added April 2008; summarized in the CFA Digest, May 2007, by Lorne Jeremy Zeiler, CFA]

The authors use a normative approach to determine whether country or industry has a greater effect on portfolio performance for emerging market equities. They test their dataset based on dispersion of returns, dispersion of utility, and option pricing. In each case, for the complete dataset, country selection has a greater effect than does industry on portfolio performance. However, when the data are examined across the three broad emerging market regions, the results are mixed. Country effect is greater in Asia, but industry effect is greater in Latin America, Europe, the Middle East, and Africa.

Fan, Joseph P.H., and T.J. Wong. 2002. "Do External Auditors Perform a Corporate Governance Role in Emerging Markets? Evidence from East Asia.” William Davidson Institute Working Paper 400.

The authors demonstrate the critical monitoring role that auditors play in emerging markets to mitigate agency problems.

Ferreira, Alex Luiz, and Miguel A. León-Ledesma. 2007. "Does the Real Interest Parity Hypothesis Hold? Evidence for Developed and Emerging Markets.” Journal of International Money and Finance, vol. 26, no. 3 (April):364-382. [added April 2008; summarized in the CFA Digest, November 2007, by Christopher J. Sullivan, CFA]

By characterizing the behavior of real interest differentials in developed and emerging economies, the authors increase the evidence supporting the real interest rate parity hypothesis for developed countries. Among emerging markets, adjustments to equilibrium rates are rapid but appear asymmetric and are driven by changing risk perceptions or threshold rate levels. The emerging economies also present a long-term differential mean larger than the near-zero mean of the developed countries. These findings comport with conjectures of highly integrated capital markets and establish the relative significance of emerging markets' higher risk premiums.

Ferreira, Miguel A., and Pedro P. Matos. 2006. "The Colors of Investors' Money: Which Firms Attract Institutional Investors from Around the World?" 2006 Darden Conference on Emerging Markets.

Institutions prefer large, liquid companies with good corporate governance. Foreign investors prefer foreign stocks that are cross-listed on U.S. exchanges, are members of major indices, and are known worldwide through analyst coverage or global sales.

Froot, Kenneth A., Paul G.J. O'Connell, and Mark S. Seasholes. 2001. "The Portfolio Flows of International Investors." Journal of Financial Economics, vol. 59, no. 2 (February):151-193.

Capital flows between countries indicate that regional factors increase in importance over time; flows are more persistent than returns; flows positively forecast future equity returns; and local stock prices are significantly sensitive to foreign flows. 
Gozzi, Juan Carlos, Ross Levine, and Sergio L. Schmukler. 2005. "Internationalization and the Evolution of Corporate Valuation.” NBER Working Paper 11023.

This paper examines long-run valuation effects of equity cross-listing and finds that much of the gain is transitory but finds little evidence that foreign country governance matters.

Harvey, Campbell R., Karl V. Lins, and Andrew H. Roper. 2004. "Effect of Capital Structure When Expected Agency Costs Are Extreme.” Journal of Financial Economics, vol. 74, no. 1 (October):3-30.

Actively monitored international debt provides an avenue for companies that face extreme managerial agency costs to commit to good behavior.

Jin, Li, and Stewart C. Myers. 2006. " $R 2$ around the World: New Theory and New Tests." Journal of Financial Economics, vol. 79, no. 2 (February):257-292.

The paper examines how low company transparency affects the division of risk bearing between inside managers and outside investors and can generate market synchronicity effects and increase the frequency of crashes.

Jostova, Gergana. 2006. "Predictability in Emerging Sovereign Debt Markets.” Journal of Business, vol. 79, no. 2 (March):527-565. [added April 2008; summarized in the CFA Digest, August 2006, by Christopher J. Sullivan, CFA]

The author presents evidence for predictability in the Brady bond market by developing a new model to describe the short-term dynamics of credit spreads. She finds that predictability is determined by spread deviations from local economic fundamentals rather than global risk factors. In the presence of informational inefficiency, active bond management strategies based on model forecasts are shown to provide excess returns to U.S. investors with reduced risk.

Lang, Mark H., Karl V. Lins, and Darius P. Miller. 2004. "Concentrated Control, Analyst Following and Valuation: Do Analysts Matter Most When Investors Are Protected Least?” Journal of Accounting Research, vol. 42, no. 3 (June):589-623.

Analyst coverage is associated with increased company valuation, especially in countries with poor country-level governance.

La Porta, Rafael, Florencio Lopez-de-Silanes, Andrei Shleifer, and Robert W. Vishny. 1997. "Legal Determinants of External Finance." Journal of Finance, vol. 52, no. 3 (July):1131-50.

This article provides comparative measures of corporate governance and shareholder protection across countries.

La Porta, Rafael, Florencio Lopez-de-Silanes, Andrei Shleifer, and Robert W. Vishny. 2002. "Investor Protection and Corporate Valuation." Journal of Finance, vol. 57, no. 3 (July):1147-70.

Better protection of minority shareholders is associated with higher valuation of companies.

Lesmond, David A. 2005. "Liquidity of Emerging Markets." Journal of Financial Economics, vol. 77, no. 2 (August):411-452.

The author evaluates the validity of several proxies for liquidity in emerging markets, with particular emphasis on zero-return day-trading costs. The paper provides some evidence on the determinants and dynamics of emerging market liquidity.

Leuz, Christian, Karl V. Lins, and Francis E. Warnock. 2005. "Do Foreigners Invest Less in Poorly Governed Firms?” 2006 Darden Conference on Emerging Markets.

This study shows that foreigners invest significantly less in poorly governed companies and in companies with ownership structures that are more conducive to governance problems. This finding is particularly pronounced in countries with weak external governance and poor information flows. 
Li, Kan, Randall Morck, Fan Yang, and B. Yeung. 2004. "Firm-Specific Variation and Openness in Emerging Markets." Review of Economics and Statistics, vol. 86, no. 3 (August):658-669.

Greater company-specific stock price variation, as opposed to market variation, is correlated with corporate governance and market openness.

Morck, Randall, and Bernard Yeung. 2002. "The Puzzle of the Harmonious Stock Prices." World Economy, vol. 3, no. 3 (July):1-15.

This article provides intuitive discussion of a "market synchronicity" effect (strong marketwide commonality in individual stock returns). The authors argue that weak protection of property rights in emerging markets explains the effect.

Morck, Randall, Bernard Yeung, and Wayne Yu. 2000. "The Information Content of Stock Markets: Why Do Emerging Markets Have Synchronous Stock Price Movements?” Journal of Financial Economics, vol. 58, nos. 1-2: 215-260.

In this first paper to document the "market synchronicity" effect (strong marketwide commonality in individual stock returns), the authors argue that weak protection of property rights in emerging markets explains the effect.

Sarkissian, Sergei, and Michael J. Schill. 2006. "Are There Permanent Valuation Gains to Overseas Listing? Evidence from Market Sequencing and Selection.” Working paper, McGill University and University of Virginia.

Valuation gains because of cross-listing are temporary and permanent gains are modest. The valuation effect is largely because of market size, liquidity, legal protections, and disclosure requirements.

Seasholes, Mark S. 2004, "Re-Examining Information Asymmetries in Emerging Stock Markets.” Working paper, University of California at Berkeley.

Foreign investors in some cases outperform local investors, contrary to standard assumptions. Foreign profit is positively related to company market capitalization and negatively related to company leverage.

Shleifer, Andrei, and Robert W. Vishny. 1997. "A Survey of Corporate Governance." Journal of Finance, vol. 52, no. 2 (April):737-783.

Legal protections and ownership concentration are important factors to consider when evaluating emerging market investments.

Siegel, Jordan I. 2005. “Can Foreign Firms Bond Themselves Effectively by Renting U.S. Securities Laws?” Journal of Financial Economics, vol. 75, no. 2 (February):319-359.

This study tests whether foreign companies can leapfrog their countries' weak legal institutions by listing equities in the U.S. and voluntarily abiding by U.S. securities law. The U.S. SEC has rarely been effective in enforcing the law against any U.S.-listed foreign company, and minority shareholders are often forced to accept token settlements as compensation. Some insiders in Mexico appear to exploit the lax enforcement and run off with the company's assets with impunity.

Speidell, Larry, Greg Stein, Kate Owsley, and Ingrid Kreuter. 2005. "Dilution Is a Drag ... The Impact of Financings in Emerging Markets.” Journal of Investing, vol. 14, no. 4 (Winter):17-22. [added April 2008; summarized in the CFA Digest, May 2006, by Lester C. Cheng, CFA]

Because emerging markets can usually offer higher diversification benefits and returns, they have been a popular subject for investors. They usually have more room for growth, a larger population, and strong ambitions for achievements. During the period between 1992 and 2002, a sample of 20 emerging countries had GDP growth of 4.2 percent per year compared with 2.9 percent for the developed countries. This outstanding growth rate might continue as advancing Internet and communication technology and booming outsourcing activities will create more job opportunities. 
However, economic prosperity does not equate to outstanding investment returns because of fierce competition, poor management, and dilution of shareholders. This article addresses the last concern by looking at growth of the economy and stock market capitalization compared with stock market returns for developed and emerging countries.

Taylor, Michael C. 2007. "Emerging Market Debt: Not So Emerging Anymore." CFA Institute Conference Proceedings Quarterly, vol. 24, no. 1 (March):55-63. [added April 2008; abstract by author]

Emerging market debt continues to evolve as an asset class. Rising credit quality among emerging market issuers and declining levels of issuance have driven spread tightening. Moreover, the growing issuance of local-currency-denominated debt creates inefficiencies that can be profitably exploited.

Warnock, Francis E., and Fang Cai. 2004. "International Diversification at Home and Abroad." SSRN working paper (December).

When choosing from among U.S. companies, both foreign and domestic investors prefer large, internationally diversified companies. For U.S. investors, this preference allows for foreign exposure even while investing in U.S. holdings. 